\title{
Dicoelitid belemnites from the Caucasian margin of the Tethys: new data from the Upper Bajocian-Lower Bathonian of Karachay-Cherkessia, southwest Russia
}

\author{
Orsana S. Dzyuba, Vasily V. Mitta \& Mikhail P. Sherstyukov
}

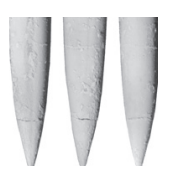

\begin{abstract}
Early representatives of the belemnite family Dicoelitidae (Belemnopseina) from the Northern Caucasus are reported from the Upper Member of the Djangura Formation of Karachay-Cherkessia. We document the first records of Dicoelites (s. str.) from the Upper Bajocian of Eastern Europe and introduce the new species Dicoelites aprilis Dzyuba sp. nov. and Dicoelites octobris Dzyuba sp. nov. Additionally, Conodicoelites sp. from the Upper Bajocian as well as a new record of Conodicoelites exiguus (Krimholz, 1953) from the Lower Bathonian are described. New belemnite records from Karachay-Cherkessia indicate the successive appearance of dicoelitid genera in the Caucasian margin of the Tethys during the Late Bajocian, i.e. Dicoelites in the late Niortense Chron and Conodicoelites in the early Garantiana Chron. Our data provide evidence supporting the presence of Dicoelites in the Bajocian deposits of the western Tethyan domain that was previously considered doubtful. - Key words: Dicoelitidae, Middle Jurassic, Bajocian, Bathonian, Northern Caucasus, western Tethys, palaeobiogeography.
\end{abstract}

Dzyuba, O.S., Mitta, V.V. \& Sherstyukov, M.P. 2019. Dicoelitid belemnites from the Caucasian margin of the Tethys: new data from the Upper Bajocian-Lower Bathonian of Karachay-Cherkessia, southwest Russia. Bulletin of Geosciences 94(4), 409-424 (5 figures, 1 table). Czech Geological Survey, Prague. ISSN 1214-1119. Manuscript received May 14, 2019; accepted in revised form September 8, 2019; published online December 10, 2019; issued December 31, 2019.

Oksana S. Dzyuba, Trofimuk Institute of Petroleum Geology and Geophysics, Siberian Branch, Russian Academy of Sciences, Academician Koptyug 3,630090 Novosibirsk, Russia; dzyubaos@ipgg.sbras・Vasily V. Mitta, Borissiak Paleontological Institute, Russian Academy of Sciences, Profsoyunznaya 123, 117647 Moscow, Russia \& Cherepovets State University, Lunacharskogo 5, 162600 Cherepovets, Russia • Mikhail P. Sherstyukov, North Caucasus Federal University, Institute of Oil and Gas, Kulakova 16/1, 355029 Stavropol, Russia

Belemnite distribution patterns in the Middle Jurassic seas are still under investigation, with many scientific surprises for both the Boreal and Tethyan domains (e.g. Dzyuba et al. 2015, 2016, 2019; Weis et al. 2015b, 2017; Challinor \& Hudson 2017; Dzyuba \& de Lagausie 2018; Ippolitov 2018a, b, c; Ippolitov \& Desai 2019). Among the early representatives of the suborder Belemnopseina Jeletzky, 1965, belemnites possessing long ventral and short dorsal alveolar grooves on the rostrum, i.e. members of the Tethyan family Dicoelitidae Sachs \& Nalnjaeva, 1967, are the least studied group, especially in the MediterraneanCaucasian Tethys (western Tethys). This family includes only two genera, elongate and hastate Dicoelites Boehm, 1906 and more robust, cylindriconical to conical Conodicoelites Stevens, 1965a.

Apart from ?Dicoelites sp. A described from the Lower Bajocian of Morocco (Weis et al. 2017, p. 221, fig. 7a, b) and "Belemnites" jacquoti Terquem \& Jourdy (1869, p. 41, pl. 1, figs 6-9) from the Upper Bajocian of northeastern France, which is presumably a dicoelitid (Weis et al. 2017), all known western Tethyan representatives of the family Dicoelitidae belong to the genus Conodicoelites (see below). The only dicoelitid belemnite described and illustrated from the Northern Caucasus is Dicoelites exiguus Krimholz (1953, p. 54, pl. 4, fig. 5). It comes from the "Upper Bajocian or Lower Bathonian" (Krimholz 1953, p. 56) of the former southern part of Stavropol Krai ( $5 \mathrm{~km}$ to the northeast of Zelenchukskaya Village), which is now a part of the Karachay-Cherkess Republic. This belemnite was later attributed to the genus Conodicoelites by Krimholz \& Repin (1989).

During fieldwork (2014 to 2018), two of us (VVM and MPSh) conducted a palaeontological-stratigraphic study of the Upper Bajocian-Lower Bathonian in KarachayCherkessia. In the course of this study, cephalopod fossil material was collected containing not only ammonites, nautilids and dicoelitid belemnites but also specimens of belemnopseid (Belemnopsis Bayle, Conobelemnopsis Riegraf, Longibelemnopsis Riegraf, Hibolithes Montfort) and megateuthidid (Megateuthis Bayle, ?Paramegateuthis Gustomesov) rostra. The current state of the art in ammonite investigations allowed us to date belemnite occur- 
rences with the chronostratigraphic units. In this report, we describe dicoelitids, introduce two new species, and discuss their palaeobiogeographic implications. The belemnites were studied by OSD and the geological setting including ammonite biostratigraphy were outlined by VVM.

\section{Geological setting and material}

All belemnites described herein come from natural outcrops located in the western part of the Northern Caucasus in Karachay-Cherkessia in the territory of the KubanUrup interfluve (Fig. 1). This territory was recognized as a typical area for the Djangura Formation, which is Bajocian-Lower Bathonian in age (Besnosov 1967). The Upper Bajocian and Lower Bathonian are represented here by terrigenous, predominantly clayey deposits with subordinate silt interlayers and are assigned to the Upper Djangura Member, which is approximately $700 \mathrm{~m}$ thick (Rostovtsev et al. 1992). The sedimentary environment is interpreted as a low energy marine setting, presumably distal shelf (Polyansky 1989). That area was situated very close to a zone of the so-called "Large Caucasus deepwater basin" located along the northern Tethyan margin between the Scythian Platform in the north and numerous terranes in the south (Rostovtsev et al. 1992, Ruban 2006, Adamia et al. 2011, Nikishin et al. 2012).
The standard Western European ammonite zones have been recognized for the Upper Member of the Djangura Formation, namely the Upper Bajocian Strenoceras niortense, Garantiana garantiana and Parkinsonia parkinsoni zones, and the Lower Bathonian Zigzagiceras zigzag Zone (Rostovtsev et al. 1992, Mitta \& Sherstyukov 2014). Nevertheless, despite the similarity of the north Caucasian ammonite assemblages to those of the western part of the western Tethys, there are also endemic taxa (or not found so far in Western Europe?), primarily at the rank of species. In addition, some taxa that are widespread in Europe are unknown in the Northern Caucasus, for example, Zigzagiceras, which is a characteristic genus of the Lower Bathonian in Western Europe. Such differences are the reason why infrazonal units in the Northern Caucasus correspond only rarely in range to the units of the Western European ammonite scale. As a result, the most characteristic ammonite taxa have been used for infrazonal subdivision of each particular interval, regardless of whether they are endemic or widespread species (Fig. 2).

A characteristic feature of the Djangura Formation outcrops in the studied area is their large extent and rarity of condensed layers that allows us to observe gradual changes in the composition of fossil assemblages. Another feature is the inaccessibility of some particular parts of the formation, owing to riverside landslides and the continuous river channel migrations. The latter

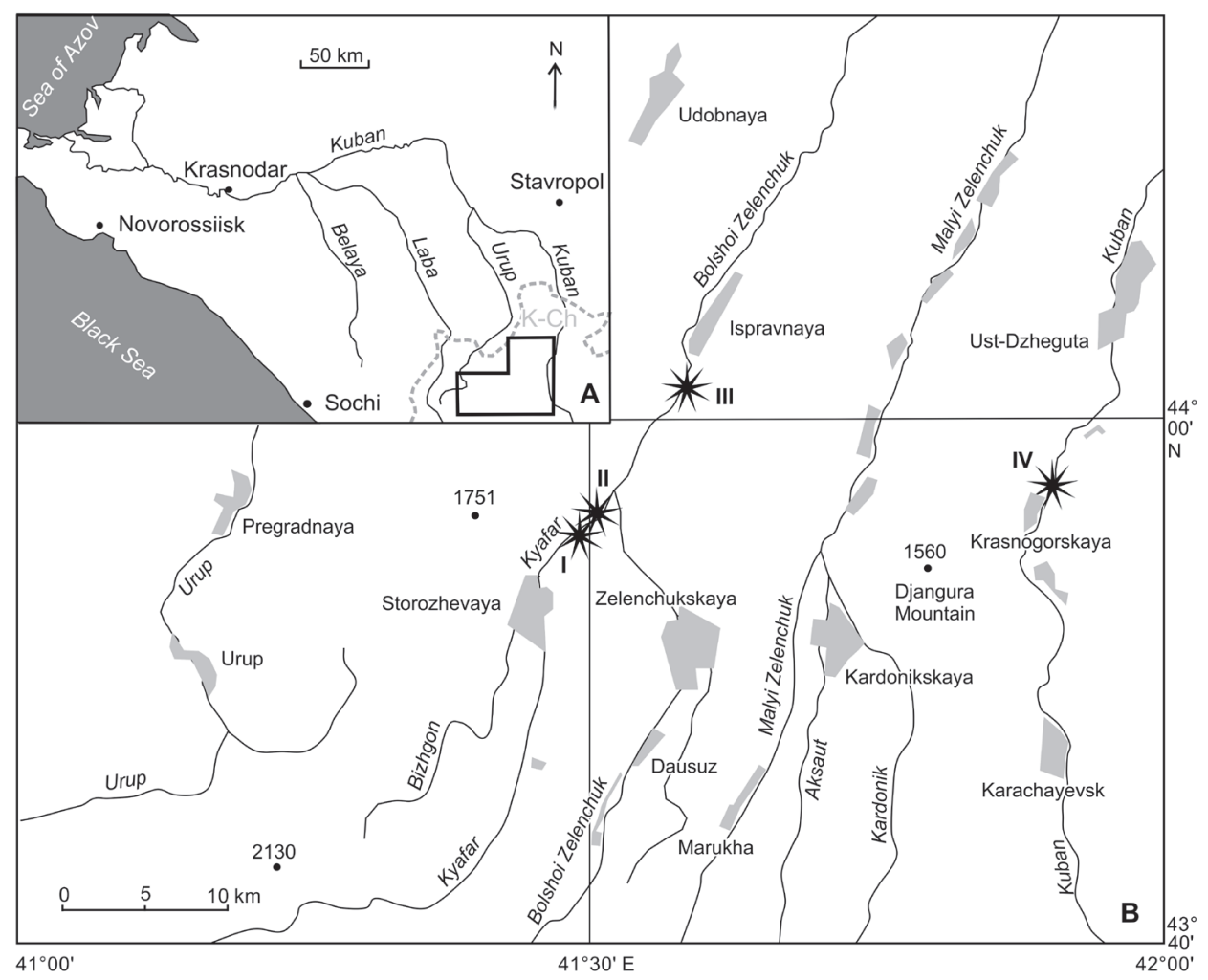

Figure 1. Location of the studied outcrops in the Kuban-Urup interfluve, Karachay-Cherkessia (K-Ch): I - localities 0-4, 5(10), 17, 30; II locality 25 ; III - locality 8 ; IV localities 19, 23. 
often makes it difficult to study the boundaries between biostratigraphic units and makes it necessary to show the uncertain placement of these boundaries on the stratigraphic scheme by dotted lines (Fig. 2). According to the Stratigraphic Code of Russia (Zhamoida 2006), such newly defined biostratigraphic units with an uncertain lower or upper boundary are referred to as "beds with ... [fossil name]" or "... [fossil name] beds". In some cases, faunal horizons as the lesser units can be recognized in the Kuban-Urup interfluve. They fit the concept of faunal horizons sensu Callomon (1964, 1985).

The Strenoceras niortense Zone is represented in the Bolshoi Zelenchuk River Basin by dark grey sandy clays, with interlayers of siltstones $(0.2-0.4 \mathrm{~m})$ and scattered carbonate nodules. The lower and middle parts of the section are assigned to the two local biostratons, Keppleritiana rostovtsevi beds and Keppleritiana graebensteini beds (Mitta 2017c), but belemnites were not found in either of these units. Several rostra were collected from the uppermost part (about $25 \mathrm{~m}$ thick) of the $S$. niortense Zone on the Kyafar River (left tributary of the Bolshoi Zelenchuk River), below the Storozhevaya Village on the left bank (locality 30), and down the river on the right bank (locality 17). Ammonites recorded from this interval are quite typical for the standard Baculatoceras baculatum Subzone: Baculatoceras spp., Spiroceras annulatum (Deshayes), Spir. bispinatum (Baugier \& Sauzé), Spir. aff. fourneti Roman \& Pétouraud, Sphaeroceras cf. tutthum S. Buckman, Calliphylloceras cf. disputabile (Zittel), Holcophylloceras zignodianum (d'Orbigny), Pseudophylloceras cf. kudernatschi (Hauer), Adabofoloceras belinskji (Besnosov), Megalytoceras sp. (Mitta \& Schweigert 2016, Mitta 2017b).

The rocks of the Garantiana garantiana Zone are exposed down the Kyafar River [e.g. locality 5(10)], but the contact with the $S$. niortense Zone is not observed here. The G. garantiana Zone is characterized by strata of grey argillite-like clays with scattered calcareous siltstone nodules, which sometimes compose nodular horizons; it is approximately $50 \mathrm{~m}$ thick. In the middle part of the strata, a horizon of clayey limestone nodules with a peculiar sedimentary structure (syneresis cracks, cone-in-cone) was recorded. This horizon appears to indicate a short interruption in sedimentation (Mitta 2019). Ammonite finds mostly come from the lower half of this zone; these are Djanaliparkinsonia alanica Mitta, Vermisphinctes martiusii (d'Orbigny), ?Garantiana sp., Holcophylloceras sp., Adabofoloceras sp., and Phylloceras sp. (Mitta $2018,2019)$. The interval under discussion is defined as the $D$. alanica beds and is considered to correspond to the Dichotoma Chronosubzone (Mitta 2019). Single specimens of Garantiana subgaranti Wetzel and Pseudogarantiana minima (Wetzel) were found in the middle part of the upper half of the G. garantiana Zone, whereas

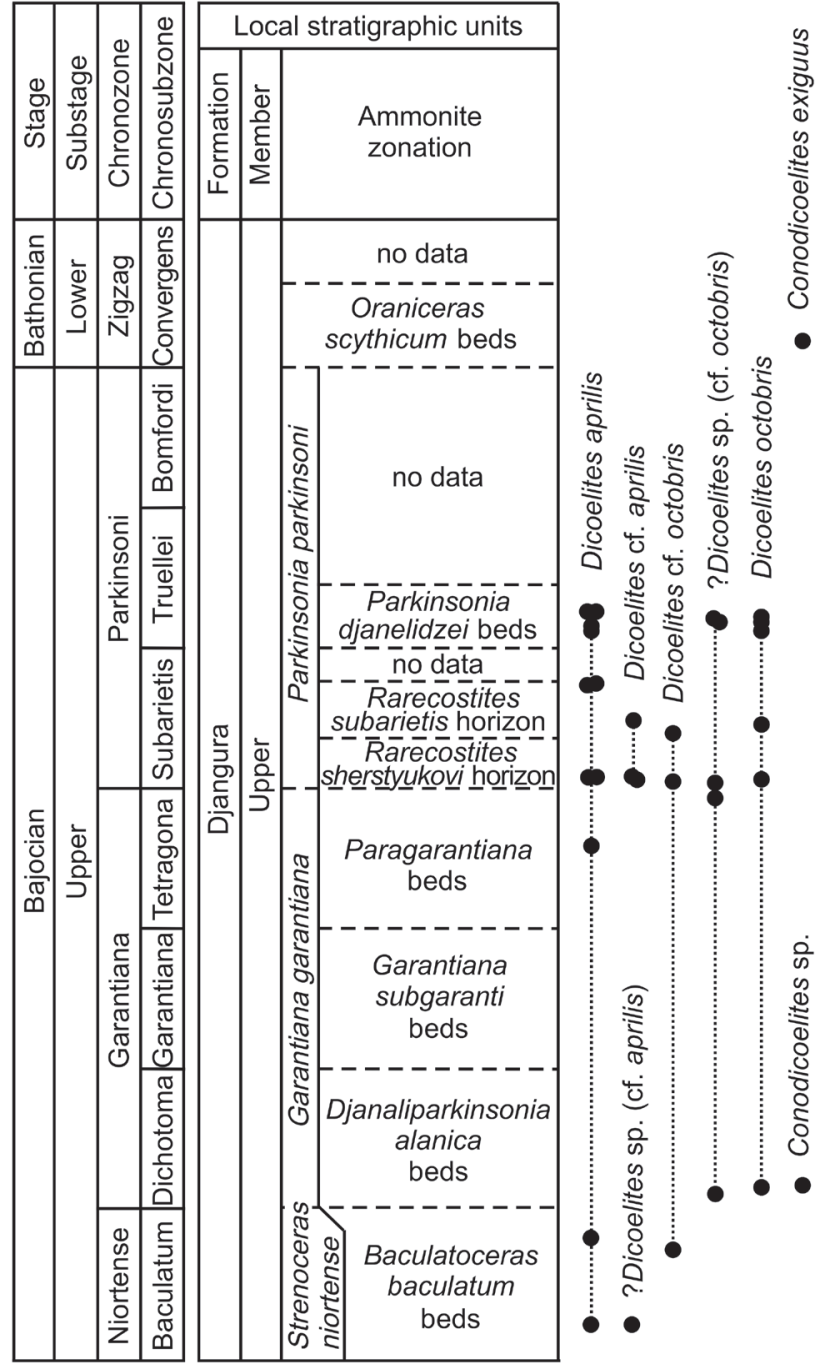

Figure 2. Stratigraphical position of dicoelitid records from the KubanUrup interfluve. Ammonite biostratigraphy is given after Mitta (2017a, 2018) and Mitta et al. (2017, 2018).

single specimens of Garantiana sp. and Paragarantiana sp. (sp. nov.?) were found in the topmost part of the zone. Regarding the local biostratigraphic scale, these findings are the reason to establish the G. subgaranti beds and the Paragarantiana beds, corresponding to the Garantiana (=Subgaranti) and Tetragona chronosubzones, respectively (Mitta 2019).

One more outcrop of the G. garantiana Zone (localities 19,23) is located on the left bank of the Kuban River, below the Krasnogorskaya Village. At low water, grey clays with calcareous siltstone nodular horizons are exposed here. These clay strata overlap sandstones of the S. niortense Zone that contain numerous Zoophycos and rare Baculatoceras sp. In the lower $2-2.5 \mathrm{~m}$ of the clay strata, Djanaliparkinsonia alanica, Vermisphinctes martiusii, Holcophylloceras sp., Dinolytoceras sp. were found (Mitta 2018). Apparently, this is the lowermost part of 
the D. alanica beds, which are basal for the G. garantiana Zone in the territory of the Kuban-Urup interfluve. Lithologically similar clays crop out down the Kuban River (upward in the section), but macrofossils were not found in them.

The lower part of the Parkinsonia parkinsoni Zone in the valley of the Kyafar River is represented by dark grey claystones with interlayers and lenses of clayey limestone; siderite nodules are scattered in the strata or form the horizons (localities $0-4$ on the right bank of the river). The total thickness of these strata exceeds $40 \mathrm{~m}$. Numerous Rarecostites have been found here: $R$. sherstyukovi Mitta, $R$. kyafarensis Mitta, R. subarietis (Wetzel), R. mutabilis (Nicolesco). Single specimens of Lissoceras haugi Sturani, Spir. obliquecostatum (Quenstedt), Patrulia karachaica Mitta, as well as transitional garantiana/ parkinsoni representatives of the genera Holcophylloceras, Calliphylloceras, Adabofoloceras, Pseudophylloceras, Dinolytoceras and Nannolytoceras were also recorded (Mitta 2017a, Mitta et al. 2018, Mitta \& Sherstyukov 2018). The ammonite faunal horizons $R$. sherstyukovi and $R$. subarietis that correspond to the lower and middle parts of the Subarietis (= Acris) Chronosubzone, respectively, were established in the studied localities (Mitta 2017a). The contact between the P. parkinsoni and the G. garantiana zones is covered by Quaternary deposits (pebbles) and therefore cannot be studied on the Kyafar River.

Down the Kyafar River (upward in the section), very thin beds of siltstones occasionally crop out from under Quaternary alluvial deposits, but macrofauna was not found in these beds. The next outcrop revealing fossils of the Parkinsonia parkinsoni Zone was studied $1.5 \mathrm{~km}$ down the river from the end of the group of localities $0-4$, on the left bank (locality 25). Grey to dark grey clays are exposed in this locality with carbonate nodules $(5-7 \mathrm{~cm}$ in diameter) scattered throughout the strata or forming the horizons. The thickness of exposed strata is about $5 \mathrm{~m}$. The ammonites Parkinsonia djanelidzei Kakhadze, rare Rarecostites donezianus (Borissjak), and numerous Dinolytoceras zhivagoi Besnosov allowed to assign this interval of the section to the $P$. djanelidzei beds (Mitta et al. 2017). Taking the presence of the last Rarecostites and the first Parkinsonia into account, these beds are considered to correspond approximately to the lowermost Truellei Chronosubzone; however, the possibility that they range up to the uppermost Subarietis Chronosubzone cannot be entirely excluded.

The Lower Bathonian part of the section is exposed on the right bank of the Bolshoi Zelenchuk River, $6.8 \mathrm{~km}$ below the mouth of the Kyafar River (e.g. locality 8). Bluish-dark grey calcareous clays with the exposed thickness not less than $7 \mathrm{~m}$ crop out here. They contain carbonate nodules, usually spherical, up to $5-15 \mathrm{~cm}$ in diameter. Macrofossils were found in situ only in the lower half of the section: frequent Oraniceras scythicum Mitta, rare Oxycerites sp., Calliphylloceras sp., Phylloceras sp., Dinolytoceras sp., and Megalytoceras sp. Very rare Cadomites sp., Polyplectites sp. and large body chambers of Perisphinctidae gen. et sp. indet. were found ex situ (Mitta 2015, Mitta et al. 2017). This interval is designated as the O. scythicum beds (Mitta et al. 2017). By the presence of a representative of the genus Oraniceras, these beds are assigned to the Lower Bathonian Zigzag Chronozone. Judging by the archaic nature of the index species, they should be correlated with the basal part of this chronozone, with the lower part of the Convergens Chronosubzone.

Thus, despite these correlations and the wealth of stratigraphic data, there are still many gaps in the infrazonal ammonite scale of the Upper Bajocian-Lower Bathonian of the Kuban-Urup interfluve. A correlation of the local stratigraphic units with the chronostratigraphic scale is shown in Fig. 2.

The 31 dicoelitid specimens examined here were collected in situ. Belemnites are relatively rare in the Upper Djangura Member. Moreover, different stratigraphic intervals are characterized by fossils in varying degrees, despite the lithological similarity of the host rocks. Most dicoelitid specimens come from the lower part of the Parkinsonia parkinsoni Zone exposed on the Kyafar River (21 specimens). Additionally, we collected four specimens from the Baculatoceras baculatum beds of the $S$. niortense Zone and two specimens from the Paragarantiana beds of the G. garantiana Zone of the Kyafar River, three specimens from the Djanaliparkinsonia alanica beds of the G. garantiana Zone of the Kuban River, and one specimen from the Oraniceras scythicum beds of the Bolshoi Zelenchuk River.

All illustrated specimens are stored in the Centre for Collective Use «Collection GEOCHRON» at the Trofimuk Institute of Petroleum Geology and Geophysics, Siberian Branch, Russian Academy of Sciences, Novosibirsk, Russia (collection no. 2069).

\section{Systematic palaeontology}

Belemnite terminology and abbreviations in the descriptions follow Doyle \& Kelly (1988): L - total preserved length; 1 - length from apex to tip of alveolus; $\mathrm{Dv}$ - dorsoventral diameter at the tip of the alveolus; Dl - lateral diameter at the tip of the alveolus; $\mathrm{Dv}_{\max }-$ maximum dorso-ventral diameter; $\mathrm{Dl}_{\max }$ - maximum lateral diameter; $\mathrm{x}$ - length from apex to maximum diameter. The degree of rostrum elongation $(1 / \mathrm{Dv}, \times 100 \%)$ and compression $(\mathrm{Dl} / \mathrm{Dv}$, $\left.\times 100 \% ; \mathrm{Dl}_{\max } / \mathrm{Dv}_{\max }, \times 100 \%\right)$ were also calculated. In cases where it was possible, we measured the apical angle 
(in the lateral plane), the alveolar angle (in the dorsoventral plane), and the ratio of the ventral radius at the tip of the alveolus to $\mathrm{Dv}, \times 100 \%$. The internal characters of the rostrum (ontogeny, position of the apical line and the alveolus, the alveolar angle) were studied in longitudinal sections. Approximate size (length) ranges are given by the terms small $(<60 \mathrm{~mm})$, medium $(60-100 \mathrm{~mm})$ and large $(>100 \mathrm{~mm})$. In most cases, rostra were coated with magnesium oxide prior to photography.

Subclass Coleoidea Bather, 1888

Order Belemnitida von Zittel, 1895

Suborder Belemnopseina Jeletzky, 1965

Family Dicoelitidae Sachs \& Nalnjaeva, 1967

\section{Genus Dicoelites Boehm, 1906}

Type species. - Belemnites dicoelus Rothpletz, 1892 by monotypy.

Occurrence. - Upper Bajocian of eastern Europe (Northern Caucasus); Bathonian-Kimmeridgian of eastern Africa, southern and south-eastern Asia, Oceania, and West Antarctica; possibly the middle Toarcian-Aalenian of north-western North America, Toarcian (?) of eastern Asia (Tibet), Bajocian and Upper Jurassic of south-western South America, Lower Bajocian of northern Africa, Upper Bajocian of Western Europe.

\section{Dicoelites aprilis Dzyuba sp. nov.}

Figure $3 \mathrm{~A}-\mathrm{K}$

Holotype. - GEOCHRON 2069/5, complete rostrum, Fig. 3A.

Type horizon and locality. - Upper Bajocian, Strenoceras niortense Zone, Baculatoceras baculatum beds; Djangura Formation, Upper Member; locality 30 on the Kyafar River, Northern Caucasus, Russia.

Material. - Holotype specimen GEOCHRON 2069/5.

Paratypes: GEOCHRON 2069/6, rostrum lacking the apical part, locality 17 on the Kyafar River, from type horizon; GEOCHRON 2069/7, subcomplete, slightly deformed rostrum, locality 5 on the Kyafar River, Garantiana garantiana Zone, Paragarantiana beds; GEOCHRON 2069/8, complete rostrum; GEOCHRON 2069/9, rostrum lacking the apical region, locality 4 on the Kyafar River, Parkinsonia parkinsoni Zone, Rarecostites sherstyukovi horizon; GEOCHRON 2069/10, subcomplete rostrum, locality 1 on the Kyafar River; GEOCHRON 2069/11, subcomplete rostrum, locality 0 on the Kyafar River, P. parkinsoni Zone, Rarecostites subarietis horizon; GEOCHRON 2069/12-2069/15, four complete or sub- complete rostra, the two of them (2069/13 and 2069/15) in combination with a phragmocone, locality 25 on the Kyafar River, P. parkinsoni Zone, Parkinsonia djanelidzei beds.

Dicoelites cf. aprilis sp. nov.: GEOCHRON $2069 / 16$, fragment of the rostrum with partly preserved alveolar and stem regions, locality 4 on the Kyafar River, $P$. parkinsoni Zone, $R$. sherstyukovi horizon, and two similar specimens from localities 3 ( $R$. subarietis horizon) and 4 on the Kyafar River.

?Dicoelites sp. (cf. aprilis sp. nov.): GEOCHRON 2069/17, rostrum lacking the alveolar region and the anterior part of the stem region, from type horizon and locality. All from the Djangura Formation, Upper Member.

Etymology - - Referring to the discovery of the holotype in April.

Diagnosis. - Medium-sized, elongate, weakly hastate rostrum. $\mathrm{Dl}_{\max }$ located slightly posterior to the mid-point. Apex acute, dorsally displaced. Long and deeply incised ventral alveolar groove. Short dorsal alveolar groove. Cross section subcircular. Alveolus occupying approximately one fourth of the rostrum.

Description. - Medium-sized, elongate rostrum (Tab. 1). The outline is symmetrical and weakly hastate. $\mathrm{Dl}_{\max }$ is located slightly posteriorly of the mid-point of the rostrum. The profile is slightly asymmetrical and weakly hastate. The apex is acute $\left(c .20-22^{\circ}\right)$ and is more or less dorsally displaced. A deeply incised, "v-shaped" ventral alveolar groove extends to the anterior apical region. This groove is combined with a splitting surface. In the alveolar region, there is commonly a shallow and "u-shaped" dorsal groove, which is faint in some individuals. The lateral lines are generally indistinct but may be represented by a wide depression in the alveolar and anterior stem regions of adult forms (Fig. $3 \mathrm{G}_{2}$ ). The cross section is subcircular, more compressed in the anterior portion of the rostrum. The alveolus is ventrally displaced (the ventral radius is $c$. $42 \%$ of Dv) and occupies approximately one-fourth of the rostrum (Fig. $3 \mathrm{H}$ ). The alveolar angle is $c .24^{\circ}$. The apical line is weakly cyrtolineate. The earliest juvenile stages are subcylindrical to hastate. The phragmocone with visible siphuncle is also preserved, indicating that the position of the longest alveolar groove is ventral (Fig. $3 \mathrm{~K}_{1}$ ).

Remarks. - D. aprilis sp. nov. resembles representatives of the genus Belemnopsis Bayle, 1878 (Belemnopseidae) in overall shape, cross section and in the possession of a long ventral alveolar groove. Moreover, a very short and shallow dorsal alveolar groove sometimes may be developed in Belemnopsis, but this feature is not recognized as a stable character for belemnopseid species. In 
some cases, both the ventral and dorsal alveolar grooves may be present on the rostrum of representatives of the genus Pseudodicoelites Sachs in Sachs \& Nalnjaeva, 1967 (Pseudodicoelitidae), but this genus is characterized by a more deeply incised and longer dorsal alveolar groove, while its ventral alveolar groove is indistinct to absent.

The new species most closely resembles ?Dicoelites jacquoti (Terquem \& Jourdy, 1869) and D. paraohangaensis Challinor \& Hudson, 2017, but is well distinguished from both these species by its less depressed cross section in the stem and apical regions, its longer ventral alveolar groove, and its dorsally displaced apex. The species differs from D. spellmanorum Challinor \& Hudson, 2017 by the latter two features and additionally by its larger size, its less hastate shape, and its less compressed cross section. It is also distinguished from $D$. paraohangaensis and $D$. spellmanorum by the better developed dorsal alveolar groove.

Some rostra in our collection represented by small fragments are not distinguishable from the species described. In case they show two alveolar grooves, these rostra are referred to as $D$. cf. aprilis sp. nov. (Tab. 1, Fig. 3L). The fragment of the rostrum with preserved posterior portion only is assigned to ?Dicoelites sp. (cf. aprilis sp. nov.) (Tab. 1, Fig. 3M).

Occurrence. - Upper Bajocian (Baculatoceras baculatum beds to Parkinsonia djanelidzei beds) of the Northern Caucasus (Karachay-Cherkessia).

\section{Dicoelites octobris Dzyuba sp. nov.}

Figure 4A-F

Holotype. - GEOCHRON 2069/18, complete rostrum, Fig. 4A.

Type horizon and locality. - Upper Bajocian, Parkinsonia parkinsoni Zone, Rarecostites subarietis horizon; Djangura Formation, Upper Member; locality 2 on the Kyafar River, Northern Caucasus, Russia.

Material. - Holotype specimen GEOCHRON 2069/18.
Paratypes: GEOCHRON 2069/19, complete rostrum, locality 23 on the Kuban River, Garantiana garantiana Zone, Djanaliparkinsonia alanica beds; GEOCHRON 2069/20, subcomplete rostrum, locality 4 on the Kyafar River, Parkinsonia parkinsoni Zone, Rarecostites sherstyukovi horizon; GEOCHRON 2069/21-2069/23, three complete or subcomplete rostra, locality 25 on the Kyafar River, P. parkinsoni Zone, Parkinsonia djanelidzei beds.

Dicoelites cf. octobris sp. nov.: GEOCHRON $2069 / 24$, fragment of the rostrum with partly preserved stem region, locality 4 on the Kyafar River, $P$. parkinsoni Zone, $R$. sherstyukovi horizon, and one similar specimen from locality 3 (Rarecostites subarietis horizon) on the Kyafar River, GEOCHRON 2069/25, rostrum lacking the alveolar region and the anterior stem region, locality 17 on the Kyafar River, Strenoceras niortense Zone, Baculatoceras baculatum beds.

?Dicoelites sp. (cf. octobris sp. nov.): GEOCHRON 2069/26, fragment of the rostrum in the rock sample, locality 19 on the Kuban River, G. garantiana Zone, $D$. alanica beds, and four rostra consisting of fragments from localities 5 (G. garantiana Zone), 4 and 25 (P. parkinsoni Zone) on the Kyafar River. All from the Djangura Formation, Upper Member.

Etymology. - Due to the discovery of the holotype in October.

Diagnosis. - Medium-sized, slender, hastate rostrum. $\mathrm{Dl}_{\max }$ located in the posterior portion. Apex acute, nearly centrally located. Moderately long, deeply incised ventral alveolar groove. Short, often faint dorsal alveolar groove. Cross section compressed, pyriform. Alveolus occupying approximately one-fifth of the rostrum.

Description. - Medium-sized, slender elongate rostrum (Tab. 1). The outline and profile are hastate, symmetrical or nearly symmetrical, with $\mathrm{Dl}_{\max }$ located in the posterior portion of the rostrum. The apex is acute $\left(c .20-22^{\circ}\right)$ and located nearly centrally. The apical line is closer to the aspect with a long alveolar groove, which consequently is considered the ventral groove. A deeply incised,

Figure 3. Dicoelites from the Upper Bajocian of Karachay-Cherkessia. $-\mathrm{A}-\mathrm{K}-$ Dicoelites aprilis Dzyuba sp. nov.; A - holotype, GEOCHRON $2069 / 5$, ventral $\left(A_{1}\right)$, right lateral $\left(A_{2}\right)$ and dorsal $\left(A_{3}\right)$ views; $B$ - GEOCHRON 2069/6, ventral $\left(B_{1}\right)$, dorsal $\left(B_{2}\right)$ views, and cross section at the posterior end $\left(B_{3}\right)$; C - GEOCHRON 2069/7, ventral $\left(C_{1}\right)$ and dorsal $\left(C_{2}\right)$ views; D - GEOCHRON 2069/8, ventral $\left(D_{1}\right)$, right lateral $\left(D_{2}\right)$ and dorsal $\left(D_{3}\right)$ views; E - GEOCHRON 2069/9, ventral $\left(\mathrm{E}_{1}\right)$, dorsal $\left(\mathrm{E}_{2}\right)$ views, and cross sections in the alveolar region $\left(\mathrm{E}_{3}\right)$ and near the point of maximum diameter $\left(\mathrm{E}_{4}\right)$; $\mathrm{F}$ - GEOCHRON 2069/10, ventral $\left(\mathrm{F}_{1}\right)$, dorsal $\left(\mathrm{F}_{2}\right)$ views, and cross sections at the anterior end $\left(\mathrm{F}_{3}\right)$ and at the posterior end $\left(\mathrm{F}_{4}\right)$; $\mathrm{G}-\mathrm{GEOCHRON}$ $2069 / 11$, ventral $\left(\mathrm{G}_{1}\right)$, right lateral $\left(\mathrm{G}_{2}\right)$, dorsal $\left(\mathrm{G}_{3}\right)$ views, and cross section at the anterior end $\left(\mathrm{G}_{4}\right)$; H - GEOCHRON 2069/12, longitudinal section; I - GEOCHRON 2069/13, ventral $\left(\mathrm{I}_{1}\right)$, right lateral $\left(\mathrm{I}_{2}\right)$, left lateral, with removed fragment $\left(\mathrm{I}_{3}\right)$, dorsal $\left(\mathrm{I}_{4}\right)$ views, and cross section at the anterior end $\left(\mathrm{I}_{5}\right)$; J - GEOCHRON 2069/14, ventral $\left(\mathrm{J}_{1}\right)$, dorsal $\left(\mathrm{J}_{2}\right)$ views, and cross section at the anterior end $\left(\mathrm{J}_{3}\right)$; K - GEOCHRON 2069/15, ventral $\left(\mathrm{K}_{1}\right)$, right lateral $\left(\mathrm{K}_{2}\right)$, dorsal $\left(\mathrm{K}_{3}\right)$ views, and cross section in the alveolar region $\left(\mathrm{K}_{4}\right) \cdot \bullet-\mathrm{L}-$ Dicoelites cf. aprilis Dzyuba sp. nov.; GEOCHRON 2069/16, ventral $\left(\mathrm{L}_{1}\right)$, dorsal $\left(\mathrm{L}_{2}\right)$ views, and cross sections at the anterior end $\left(\mathrm{L}_{3}\right)$ and at the posterior end $\left(\mathrm{L}_{4}\right) \cdot \bullet \mathrm{M}-$ ?Dicoelites sp. (cf. aprilis Dzyuba sp. nov.); GEOCHRON 2069/17, ventral $\left(\mathrm{M}_{1}\right)$, right lateral $\left(\mathrm{M}_{2}\right)$, dorsal $\left(\mathrm{M}_{3}\right)$ views, and cross section at the anterior end $\left(\mathrm{M}_{4}\right)$. Scale bar is $10 \mathrm{~mm}$. 


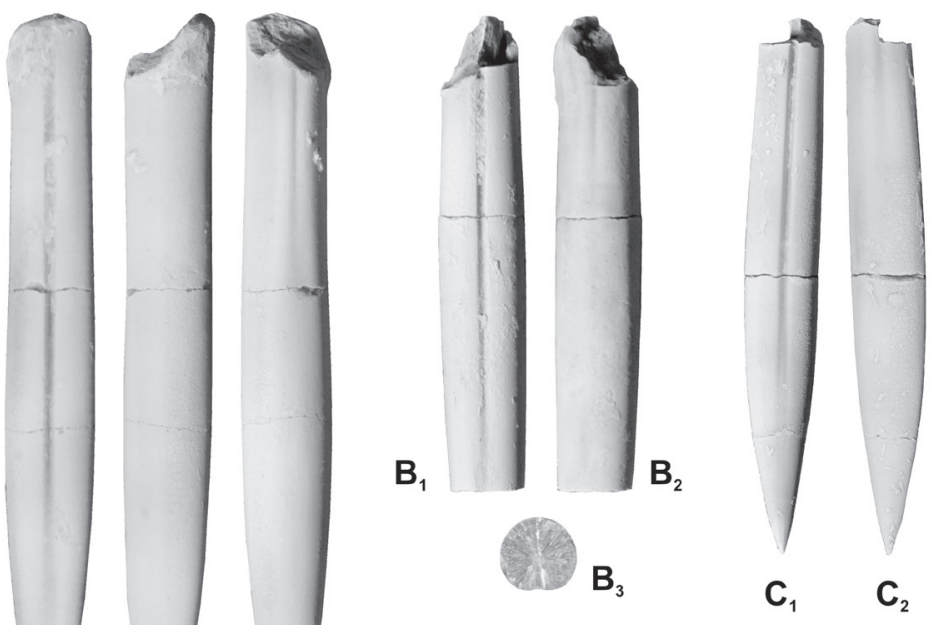

$\mathbf{G}_{4}$

$\begin{array}{lll}A_{1} & A_{2} & A_{3}\end{array}$

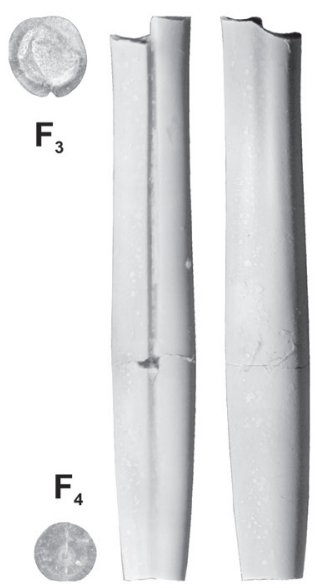

$F_{1} \quad F_{2}$
$\mathbf{G}_{1} \quad \mathbf{G}_{2}$

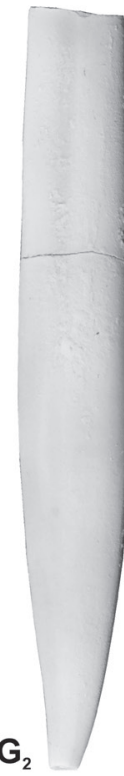

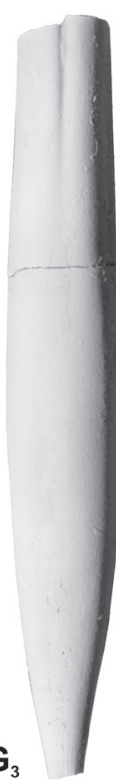

$\mathbf{G}_{3}$

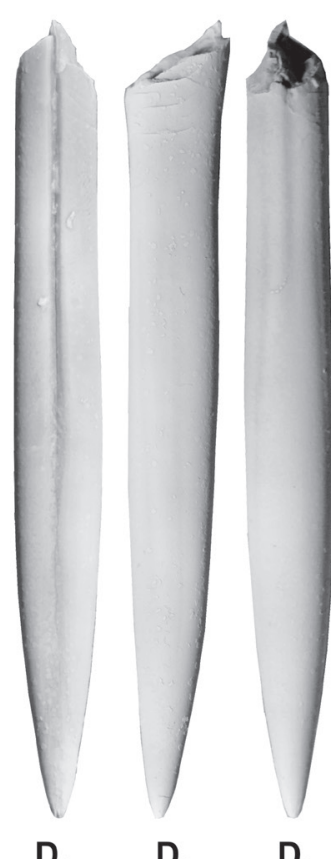

$E_{3} \bigcirc$

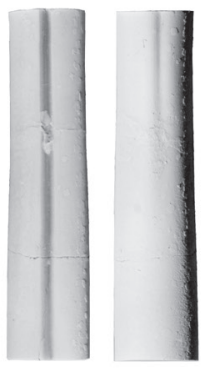

$E_{1} \quad E_{2}$

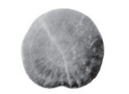

$\mathrm{E}_{4}$
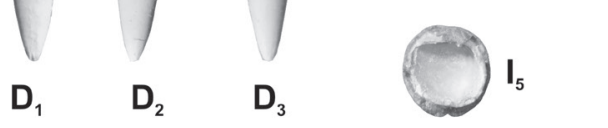
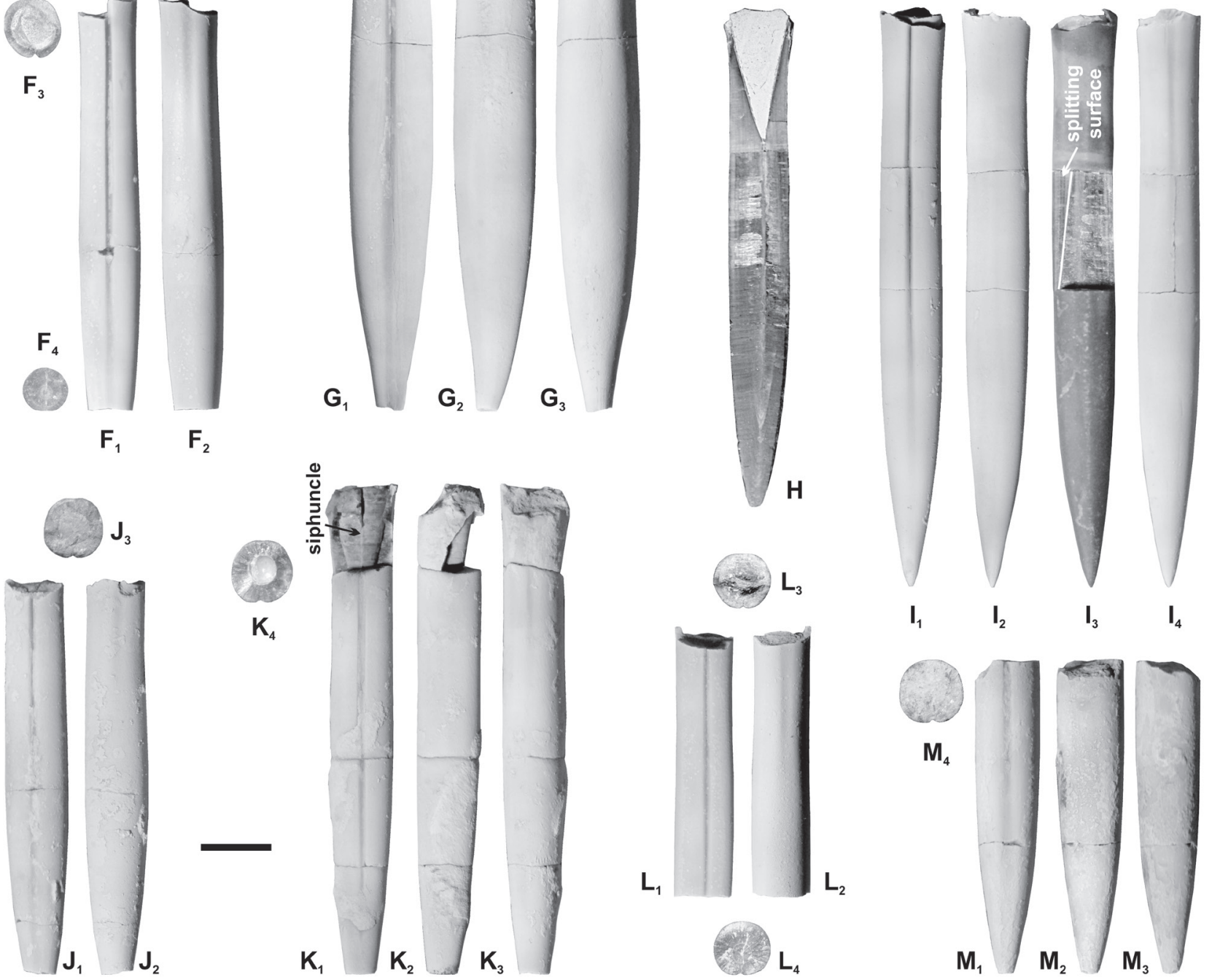
"v-shaped" ventral groove is developed in the alveolar and stem regions; posteriorly, the groove widens and shallows considerably. A ventral splitting surface is present. The dorsal alveolar groove is relatively short, "u-shaped" and often faint. The lateral lines may be slightly prominent. The cross section is compressed and pyriform. The alveolus is ventrally displaced (the ventral radius is $c .43 \%$ of Dv) and occupies approximately one-fifth of the rostrum (Fig. 4D). The alveolar angle is $c .27^{\circ}$. The apical line is weakly cyrtolineate to almost goniolineate. The earliest juvenile stages are hastate.

Remarks. - In general shape and cross section, D. octobris sp. nov. is close to representatives of the genus Hibolithes Montfort, 1808 (Belemnopseidae), but differs by its longer ventral alveolar groove and by having a dorsal alveolar groove as a stable character (at least in the rostra studied). The new species is similar to D. spellmanorum Challinor \& Hudson, 2017 in having a slender hastate rostrum with a compressed cross section, but differs in its somewhat larger size, its better developed alveolar grooves, and the fact that its maximum diameter is located closer to the apex. The species is distinguished from $D$. aprilis sp. nov. by the latter feature and additionally by its somewhat smaller size, its more slender shape, its compressed cross section, its shorter ventral alveolar groove, and its almost non-eccentric apex. The new species is less elongate than D. aviasi Challinor \& Grant-Mackie, 1989 and some other closely related species.

The fragments of the compressed rostra showing two alveolar grooves are referred to as $D$. cf. octobris sp. nov. (Tab. 1, Fig. 4G, H). More questionable fragments are assigned to ?Dicoelites sp. (cf. octobris sp. nov.) (Tab. 1, Fig. 4I).

Occurrence. - Upper Bajocian (Djanaliparkinsonia alanica beds to Parkinsonia djanelidzei beds, possibly the Baculatoceras baculatum beds) of the Northern Caucasus (Karachay-Cherkessia).

\section{Genus Conodicoelites Stevens, 1965a}

Type species. - Dicoelites keeuwensis Boehm, 1912 by original designation.

Occurrence. - Toarcian of north-western North America; Upper Bajocian-Callovian, as well as possibly Toarcian and Portlandian of Europe (with the exception of Northern Europe); Bathonian-Lower Kimmeridgian of southwestern, southern and south-eastern Asia, Oceania, and West Antarctica.

\section{Conodicoelites exiguus (Krimholz, 1953)}

Figure $4 \mathrm{~J}-\mathrm{L}$
1953 Dicoelites exiguus sp. n.; Krimholz, p. 54, pl. 4, fig. 5.

1961 Dicoelites exiguus Krimholz. - Sibiryakova, p. 53, pl. 6, fig. 6.

1989 Conodicoelites repini Krimholz, sp. nov. - Krimholz \& Repin, p. 92, pl. 1, fig. 3.

Types. - Two specimens, 210/21 and 210/22, from the same collection and locality, St. Petersburg University, Paleontological and Stratigraphic Museum (SPbU PSM), Russia; Djangura Formation, Upper Member; $5 \mathrm{~km}$ to the northeast of Zelenchukskaya Village, Northern Caucasus, Russia. Krimholz (1953) did not designate a holotype. The subcomplete rostrum, specimen no. 210/21, illustrated and described by Krimholz (1953, p. 54, pl. 4, fig. 5), is hereby designated as the lectotype and re-illustrated (Fig. 4J). A fragment of a rostrum represents another specimen of a former syntype series. This specimen, no. 210/22, is hereby designated as the paralectotype and is illustrated herein for the first time (Fig. 4K).

Material. - GEOCHRON 2069/27, complete rostrum, locality 8 on the Bolshoi Zelenchuk River, Oraniceras scythicum beds, Djangura Formation, Upper Member.

Diagnosis. - Medium-sized, moderately robust, cylindriconical to conical rostrum. Apex acute, dorsally displaced. Long and deeply incised ventral alveolar groove. Short and deeply incised dorsal alveolar groove. Cross section subcircular. Alveolus occupying one-third to two-fifths of the rostrum.

Description. - Medium-sized, moderately robust rostrum (Tab. 1). The outline is symmetrical and cylindriconical. The profile is asymmetrical, cylindriconical to conical. By analogy with the lectotype and paralectotype, the aspect with the longest alveolar groove is considered by us the venter. The venter is significantly inflated in the apical region, and the dorsum is only slightly inflated. The apex is acute $\left(c .26^{\circ}\right)$ and dorsally displaced. A deeply incised, "v-shaped" ventral alveolar groove extends up to the anterior apical region, where it gradually widens and shallows. A deeply incised, "v-shaped" dorsal groove is well developed throughout the alveolar region. Both ventral and dorsal splitting surfaces may be present but not visible. The lateral lines are indistinct. The cross section is subcircular and almost equidimensional in the stem and apical regions, but slightly compressed in the alveolar region. The alveolus occupies approximately one-third of the rostrum.

Remarks. - The species strongly resembles C. meyrati (Ooster, 1857) but differs by having a shorter dorsal alveolar groove and a less compressed cross section. The 

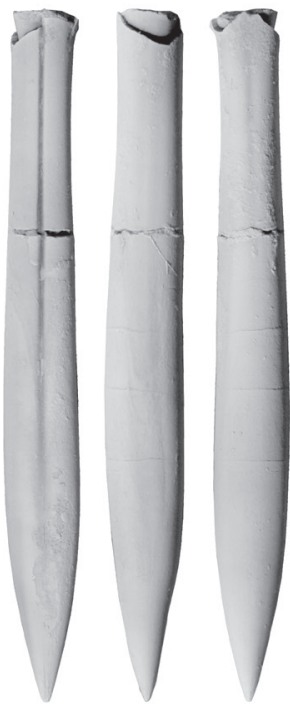

$\mathbf{A}_{1}$

$\mathbf{A}_{3}$

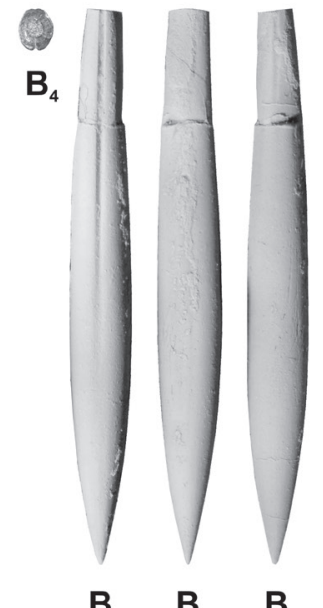

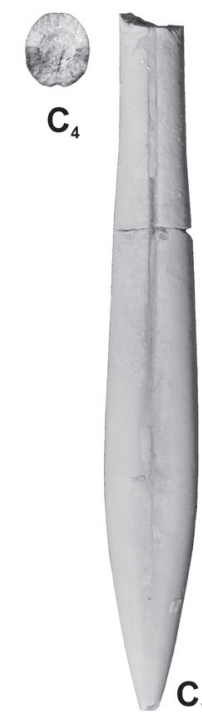
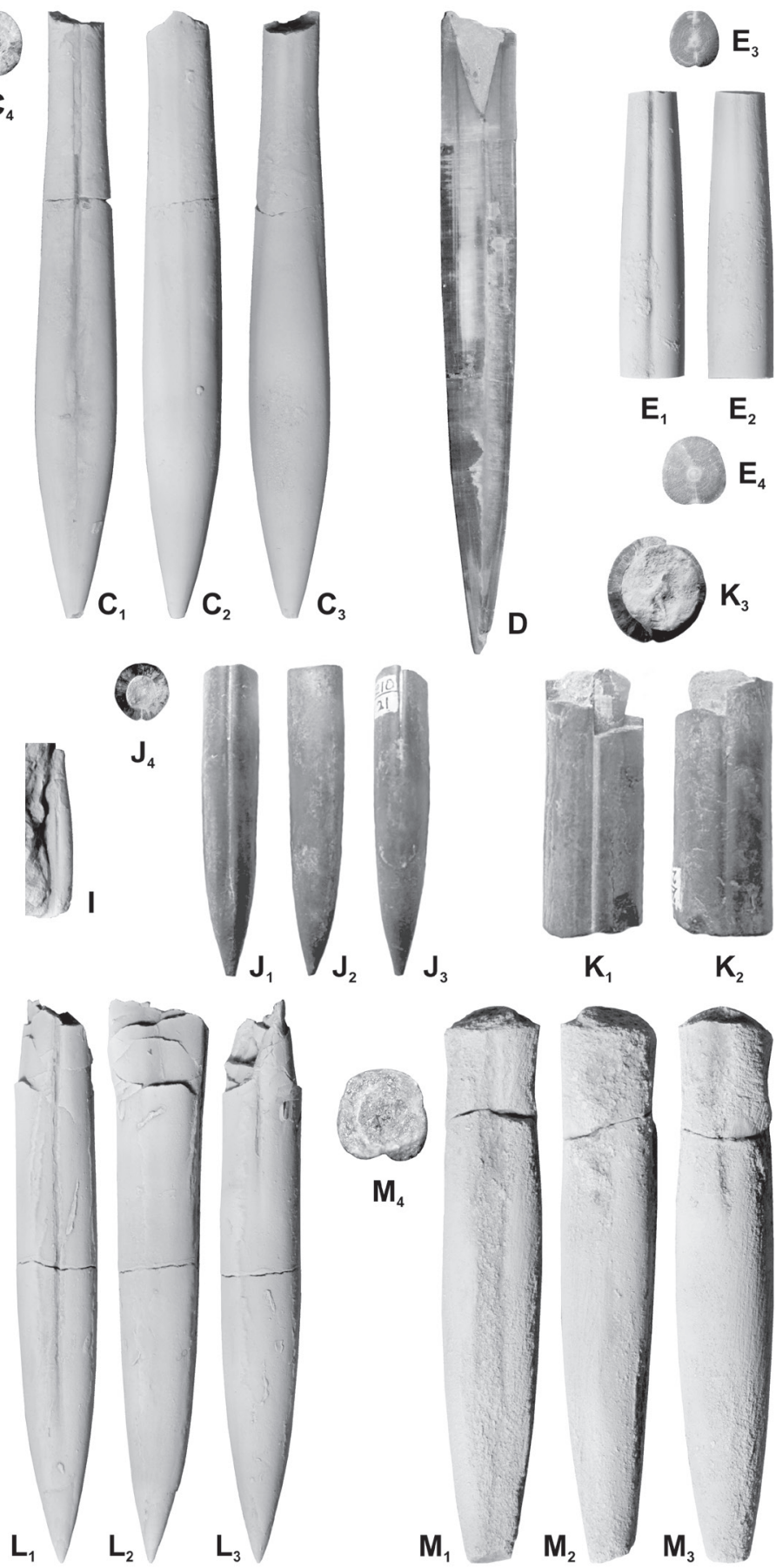
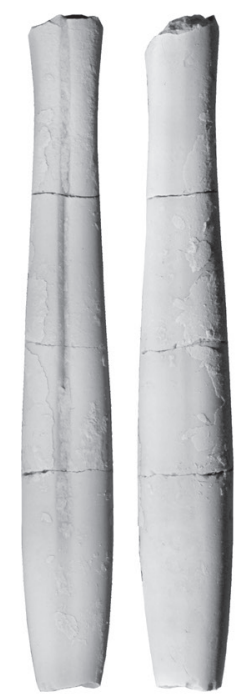

$\mathbf{F}_{1}$

$\mathbf{F}_{2}$

$\mathbf{F}_{3}$

$\mathbf{F}_{4}$

$\mathbf{G}_{1} \quad \mathbf{G}_{2}$

Figure 4. Dicoelites and Conodicoelites from the Upper Bajocian (A-I, M) and Lower Bathonian (J-L) of Karachay-Cherkessia. $-\mathrm{A}-\mathrm{F}-$ Dicoelites octobris Dzyuba sp. nov.; A - holotype, GEOCHRON 2069/18, ventral $\left(\mathrm{A}_{1}\right)$, right lateral $\left(\mathrm{A}_{2}\right)$ and dorsal $\left(\mathrm{A}_{3}\right)$ views; B - GEOCHRON 2069/19, ventral $\left(B_{1}\right)$, right lateral $\left(B_{2}\right)$, dorsal $\left(B_{3}\right)$ views, and cross section at the anterior end $\left(B_{4}\right) ; C-$ GEOCHRON 2069/20, ventral $\left(C_{1}\right)$, right lateral $\left(C_{2}\right)$, dorsal $\left(\mathrm{C}_{3}\right)$ views, and cross section at the anterior end $\left(\mathrm{C}_{4}\right)$; D - GEOCHRON 2069/21, longitudinal section not ideally prepared; E -GEOCHRON $2069 / 22$, ventral $\left(E_{1}\right)$, dorsal $\left(E_{2}\right)$ views, and cross sections near the tip of the alveolus $\left(E_{3}\right)$ and near the point of maximum diameter $\left(E_{4}\right) ; F-G E O-$ CHRON 2069/23, ventral $\left(\mathrm{F}_{1}\right)$, right lateral $\left(\mathrm{F}_{2}\right)$, dorsal $\left(\mathrm{F}_{3}\right)$ views, and cross section at the posterior end $\left(\mathrm{F}_{4}\right) \cdot \bullet \mathrm{G}, \mathrm{H}-$ Dicoelites cf. octobris Dzyuba sp. nov.; $\mathrm{G}$ - GEOCHRON 2069/24, ventral $\left(\mathrm{G}_{1}\right)$, dorsal $\left(\mathrm{G}_{2}\right)$ views, and cross section near the tip of the alveolus $\left(\mathrm{G}_{3}\right)$; H - GEOCHRON 2069/25, ventral $\left(\mathrm{H}_{1}\right)$, right lateral $\left(\mathrm{H}_{2}\right)$, dorsal $\left(\mathrm{H}_{3}\right)$ views, and cross section at the anterior end $\left(\mathrm{H}_{4}\right) \cdot \bullet \mathrm{I}-$ ?Dicoelites sp. (cf. octobris Dzyuba sp. nov.); GEOCHRON 2069/26, fragment of the rostrum (ventral view) in the rock sample. $・ \mathrm{~J}-\mathrm{L}$ - Conodicoelites exiguus (Krimholz, 1953); J - lectotype, SPbU PSM 210/21, ventral $\left(\mathrm{J}_{1}\right)$, right lateral $\left(\mathrm{J}_{2}\right)$, dorsal $\left(\mathrm{J}_{3}\right)$ views, and cross section at the anterior end $\left(\mathrm{J}_{4}\right) ; \mathrm{K}$ - paralectotype, SPbU PSM $210 / 22$, ventral $\left(\mathrm{K}_{1}\right)$, dorsal $\left(\mathrm{K}_{2}\right)$

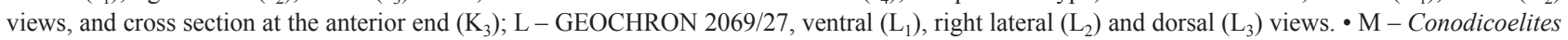
sp.; GEOCHRON 2069/28, ventral $\left(\mathrm{M}_{1}\right)$, right lateral $\left(\mathrm{M}_{2}\right)$, dorsal $\left(\mathrm{M}_{3}\right)$ views, and cross section in the alveolar region $\left(\mathrm{M}_{4}\right)$. Scale bar is $10 \mathrm{~mm}$. 
specimen described was found approximately $15 \mathrm{~km}$ to the north of Zelenchukskaya Village that is not far from the type locality indicated by Krimholz (1953) for the species. Taking this new record as well as the record of $C$. exiguus from Turkmenistan (Sibiryakova 1961) into account, we conclude that the lectotype and paralectotype come from the Lower Bathonian rather than from the Upper Bajocian. The species C. repini Krimholz in Krimholz \& Repin, 1989 is based on a single rostrum lacking the apex, which can be assigned to $C$. exiguus. This rostrum was found in the Lower-Middle Bathonian transition beds of Iran; in our opinion, it fulfils the diagnostic criteria for C. exiguus. Therefore, the name $C$. repini is included here in the synonymy of $C$. exiguus.

Occurrence. - Lower Bathonian of the Northern Caucasus (Karachay-Cherkessia) and Turkmenistan; Lower-Middle Bathonian transition of Iran.

\section{Conodicoelites sp.}

Figure 4M

Material. - GEOCHRON 2069/28, rostrum lacking the apex, locality 19 on the Kuban River, Garantiana garantiana Zone, Djanaliparkinsonia alanica beds, Djangura Formation, Upper Member.

Description. - Medium-sized, moderately robust rostrum (Tab. 1). The outline is symmetrical and weakly hastate. The profile is asymmetrical, cylindriconical to conical. By analogy with $C$. exiguus, the aspect with the longest alveolar groove is considered to be the venter. The venter is flattened and the dorsum is slightly inflated. The apex is acute. Since our material comprises only one single rostrum, which is only incompletely preserved, we cannot examine and describe the alveolar grooves in detail. Nevertheless, it is clear that the ventral groove extends to the apical region, while the dorsal groove is confined to the alveolar region. The specimen shows no evidence of splitting surfaces associated with grooves although they may be present. The lateral lines are represented by a narrow groove-like depression in the alveolar region. The cross section is subquadrate, being slightly compressed in the anterior alveolar region and slightly depressed at the tip of the alveolus; the degree of rostrum depression increases toward the apex. The alveolus occupies approximately one-third of the rostrum.

Remarks. - The specimen somewhat resembles $C$. exiguus but is weakly hastate in outline, less asymmetrical in profile, and has a flattened venter. We abstain from describing a new species based on a single specimen. The specimen is close to C. waageni (Neumayr, 1871), but this species differs by its longer dorsal alveolar groove. The same concern applies to the morphologically closest species C. riljensis Gaković \& Stoyanova-Vergilova, 1978 and C. nishavaensis Stoyanova-Vergilova, 1979; additionally, the former species is distinguished by its depressed cross section in the anterior alveolar region, while the latter is compressed on the entire length of its rostrum and has a more cylindrical rostrum shape with an inflated venter.

Occurrence. - Upper Bajocian (Djanaliparkinsonia alanica beds) of the Northern Caucasus (Karachay-Cherkessia).

\section{Discussion}

\section{Dicoelitid belemnites of the western Tethys}

New belemnite records from the Northern Caucasus (Karachay-Cherkessia) contribute to the palaeontological characteristics of the Mediterranean belemnite province of the Tethyan Realm sensu Challinor et al. (1992) or the Mediterranean-Caucasian faunal Subrealm of the Tethyan Realm sensu Westermann (2000) in Bajocian time. Our data provide evidence supporting the presence of Dicoelites in the Bajocian deposits of the western Tethyan domain. Two new species, D. aprilis Dzyuba sp. nov. and D. octobris Dzyuba sp. nov., are recorded from the Upper Bajocian of the southern part of eastern Europe. These new data significantly increase the possibility that ?Dicoelites sp. A from the Lower Bajocian (Laeviuscula Chronozone) of Morocco (Weis et al. 2017) and "Belemnites" jacquoti Terquem \& Jourdy, 1869 from the Upper Bajocian of north-eastern France belong to the genus Dicoelites. The latter two taxa, both characterized by a rostrum with alveolar grooves of different length and depth in ventral and dorsal positions, were identified based on limited material. It cannot be excluded that these rostra are of individuals with developed dorsal groove and belong to one of the belemnopseid genera, Belemnopsis or Hibolithes. This possibility precludes us from assigning them to Dicoelites with certainty. Although the position of the alveolar grooves on the rostra (dorsal vs. ventral) was not precisely defined, we have major doubts about the relevance of their assignment to the genus Pseudodicoelites (Pseudodicoelitidae), which is characterized by a long dorso-alveolar groove and some-times by a short ventroalveolar groove but is an exclusively boreal taxon (Sachs \& Nalnjaeva 1975, Jeletzky 1980).

The single rostrum identified herein as Conodicoelites sp., which probably belongs to the new unknown species, is reported from the Upper Bajocian (Garantiana Chronozone) of the Northern Caucasus. The species C. exiguus (Krimholz, 1953) is recorded herein from the Lower Bathonian (Zigzag Chronozone) with certainty, being previously known in the Northern Caucasus as 
Table 1. Measurements of the studied belemnites. Abbreviations: * - measured at the anterior end; $\mathrm{L}-$ total preserved length; $1-$ length from apex to tip of alveolus; $\mathrm{Dv}$ - dorso-ventral diameter at the tip of the alveolus; $\mathrm{Dl}$ - lateral diameter at the tip of the alveolus; $\mathrm{Dv} \mathrm{vax}_{\max }-\operatorname{maximum}_{\mathrm{m}}$ dorsoventral diameter; $\mathrm{Dl}_{\max }-$ maximum lateral diameter; $\mathrm{x}$ - length from apex to maximum diameter; $(1 / \mathrm{Dv}, \times 100 \%)-$ degree of rostrum elongation; $\left(\mathrm{Dl} / \mathrm{Dv}, \times 100 \% ; \mathrm{Dl}_{\max } / \mathrm{Dv}_{\max }, \times 100 \%\right)-$ compression.

\begin{tabular}{|c|c|c|c|c|c|c|c|c|c|c|}
\hline Specimen no. & $\begin{array}{c}\mathrm{L}, \\
\mathrm{mm}\end{array}$ & $\begin{array}{c}1, \\
\mathrm{~mm}\end{array}$ & $\begin{array}{l}\mathrm{Dv} \\
\mathrm{mm}\end{array}$ & $\begin{array}{l}\mathrm{Dl}, \\
\mathrm{mm}\end{array}$ & $\begin{array}{c}\mathrm{Dv}_{\max }, \\
\mathrm{mm}\end{array}$ & $\begin{array}{c}\mathrm{D} 1_{\max }, \\
\mathrm{mm}\end{array}$ & $\begin{array}{l}\mathrm{x} \\
\mathrm{mm}\end{array}$ & $\begin{array}{c}1 / \mathrm{Dv}, \times \\
100 \%\end{array}$ & $\begin{array}{c}\mathrm{D} 1 / \mathrm{Dv}, \times \\
100 \%\end{array}$ & $\begin{array}{c}\mathrm{Dl}_{\max } / \mathrm{Dv}_{\max }, \times \\
100 \%\end{array}$ \\
\hline \multicolumn{11}{|c|}{ Dicoelites aprilis Dzyuba sp. nov. } \\
\hline GEOCHRON 2069/5 & 79.6 & 53.0 & 8.6 & 8.7 & 9.0 & 9.3 & 36.0 & 616 & 101 & 103 \\
\hline GEOCHRON 2069/6 & 49.3 & - & 8.7 & 8.7 & 8.8 & 8.9 & - & - & 100 & 101 \\
\hline GEOCHRON 2069/7 & 55.6 & 53.0 & 7.1 & 6.8 & 7.2 & 7.5 & 29.0 & 746 & 96 & 104 \\
\hline GEOCHRON 2069/8 & 82.8 & 55.5 & 9.2 & 8.6 & 9.1 & 9.2 & 38.5 & 603 & 93 & 101 \\
\hline GEOCHRON 2069/9 & 36.3 & - & 8.3 & 7.8 & 8.4 & 8.6 & - & - & 94 & 102 \\
\hline GEOCHRON 2069/10 & 58.5 & - & 8.1 & 7.8 & 8.4 & 8.6 & - & - & 96 & 102 \\
\hline GEOCHRON 2069/11 & 79.2 & $\sim 66.0$ & 10.9 & 10.6 & 11.5 & 11.7 & $\sim 38.0$ & 606 & 97 & 102 \\
\hline GEOCHRON 2069/12 & 71.0 & 51.9 & 8.4 & 8.2 & 8.7 & 9.0 & 34.0 & 618 & 98 & 103 \\
\hline GEOCHRON 2069/13 & 82.3 & 59.7 & 8.7 & 8.4 & 8.9 & 8.8 & 42.5 & 686 & 97 & 99 \\
\hline GEOCHRON 2069/14 & 56.2 & - & 8.5 & 8.2 & 8.7 & 9.0 & - & - & 96 & 103 \\
\hline GEOCHRON 2069/15 & 69.8 & - & 8.6 & 8.5 & 8.8 & 8.8 & - & - & 99 & 100 \\
\hline
\end{tabular}

Dicoelites cf. aprilis Dzyuba sp. nov.

?DEOCHRON 2069/16 $\quad 38.6$

GEOCHRON 2069/17 44.6

$\begin{array}{llll}7.7 & 7.8 & 7.9 & 8.2\end{array}$

$-$

$\begin{array}{ll}- & 101\end{array}$

104

\begin{tabular}{lcccccccccc} 
GEOCHRON 2069/17 & 44.6 & - & - & - & 9.0 & 9.1 & 39.0 & - & - & 101 \\
\hline Dicoelites octobris Dzyuba sp. nov. & & & & & & & & \\
GEOCHRON 2069/18 & 71.8 & 56.7 & 6.8 & 6.2 & 8.0 & 7.8 & 25.0 & 834 & 91 & 98 \\
GEOCHRON 2069/19 & 57.7 & 56.0 & 4.3 & 3.7 & 6.6 & 6.4 & 23.0 & 1302 & 86 & 97 \\
GEOCHRON 2069/20 & 72.4 & 65.0 & 7.6 & 6.7 & 9.4 & 9.6 & 24.0 & 855 & 88 & 102 \\
GEOCHRON 2069/21 & 76.6 & 64.1 & 9.1 & 8.0 & - & - & - & 704 & 88 & - \\
GEOCHRON 2069/22 & 34.3 & - & 6.8 & 5.9 & 8.2 & 7.6 & - & - & 87 & 93 \\
GEOCHRON 2069/23 & 70.2 & - & 6.9 & 6.5 & 9.9 & 9.4 & - & - & 94 & 95
\end{tabular}

Dicoelites cf. octobris Dzyuba sp. nov.

$\begin{array}{lllllllllll}\text { GEOCHRON 2069/24 } & 12.8 & - & 6.3 & 5.8 & - & - & - & - & 92 & - \\ \text { GEOCHRON 2069/25 } & 52.9 & - & 7.9^{*} & 7.1^{*} & 8.1 & 7.9 & 25.5 & - & 90^{*} & 98\end{array}$

?Dicoelites sp. (cf. octobris Dzyuba sp. nov.)

GEOCHRON 2069/26 20.0

Conodicoelites exiguus (Krimholz, 1953)

\begin{tabular}{lllll} 
GEOCHRON 2069/27 & 67.2 & 46.9 & 9.5 & 9.3 \\
\hline
\end{tabular}

Conodicoelites sp.

GEOCHRON 2069/28

64.7

$11.1 \quad 11.5$

$\begin{array}{lllll}- & - & - & 494 & 98\end{array}$

originating from the "Upper Bajocian or Lower Bathonian". The representatives of this species were also illustrated and described from southwestern Asia, where they were found in the Lower Bathonian of Turkmenistan (Sibiryakova 1961) and the Lower-Middle Bathonian transition beds of Iran (Krimholz \& Repin 1989, as C. repini Krimholz, sp. nov.). Besides C. exiguus, some other species of the genus Conodicoelites are known from the western Tethyan domain. In southeastern Europe, C. riljensis Gaković \& Stoyanova-Vergilova (1978, p. 419, pl. 1, fig. 1) was discovered in Bosnia and Herzegovina, being recorded from the "upper part of Domerian", which is currently assigned to the Lower Toarcian Tenuicostatum Chronozone (for discussion see Weis et al. 2015a). The two 

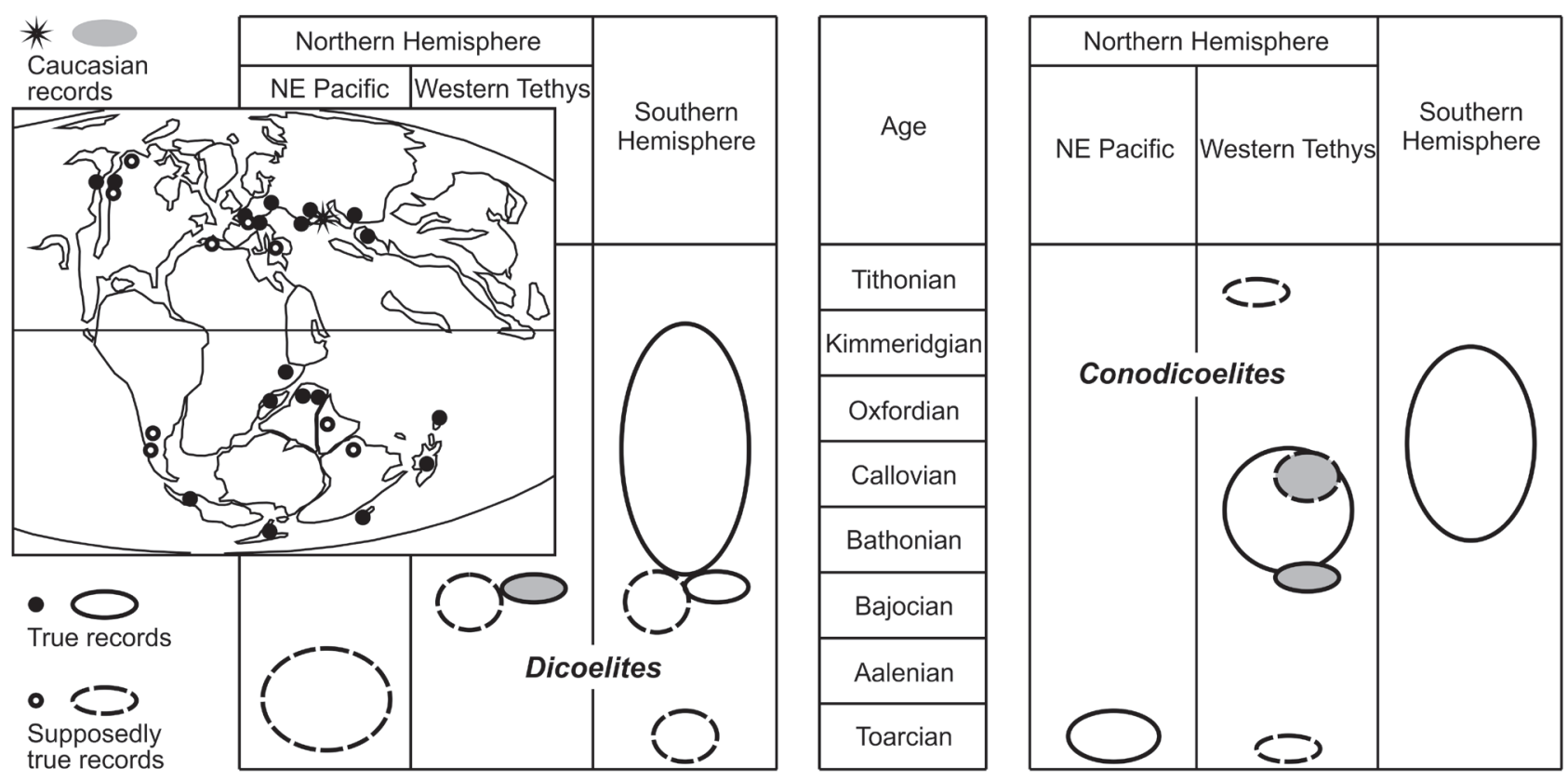

Figure 5. Dicoelitid distribution pattern. Compiled from numerous sources (see text). Generalized plate tectonic map of Jurassic is based on Scotese (2004) and Golonka (2011).

species C. glojenensis Stoyanova-Vergilova (1979, p. 55, pl. 3, fig. 2) and C. nishavaensis Stoyanova-Vergilova (1979, p. 55, pl. 3, fig. 1) were reported from the Bathonian of Bulgaria. However, the western Tethyan representatives of Conodicoelites are more common in the Callovian; they were recognized in France, Switzerland, Poland, and the Crimea (e.g. Bülow-Trummer 1920, Krimholz 1931, Pugaczewska 1961) under the generic name Dicoelites prior to the publication of the generic name Conodicoelites proposed by Stevens (1965a). Conodicoelites keeuwensis (Boehm, 1912) was mentioned but not illustrated for the Callovian of western Abkhazia, the Southern Caucasus (Krimholz in Rostovtsev et al. 1992). The species "Belemnites" pellati de Loriol in Loriol \& Pellat (1874, p. 14, pl. 1, fig. 10) recorded from the middle Portlandian of France is also similar to Conodicoelites in having a robust rostrum with two alveolar grooves in ventral and dorsal positions, although its affiliation to Dicoelitidae is usually questioned (e.g. Bülow-Trummer 1920, Stevens 1965a). According to Weis et al. (2015b), the AalenianLower Bajocian west-Tethyan species "Belemnites" avena Dumortier in Mayer 1866, previously considered as a representative of Dicoelites (e.g. Boehm 1912, BülowTrummer 1920), belongs to the genus Rhabdobelus Naef, 1922 of the family Hastitidae (Belemnitina).

In the Late Aalenian-Early Bajocian, the Caucasian belemnite communities were represented by a mixed belemnitin-belemnopsein fauna that was characteristic for the area from southern England to northern Iran (Weis et al. 2017). In the Late Bajocian, however, the communities were dominated by belemnopseins in the area of KarachayCherkessia (herein and unpublished data). This change in the taxonomic structure of the belemnite fauna displays a gradual displacement of belemnitins by belemnopseins, distinctive for the Tethyan seas during Bajocian-Bathonian times (e.g. Doyle \& Bennet 1995, Weis et al. 2017). New data described herein indicate the successive appearance of dicoelitid genera in the Caucasian margin of the Tethys during the Late Bajocian, i.e. Dicoelites in the late Niortense Chron and Conodicoelites in the early Garantiana Chron, both before mid-Late Bajocian time.

\section{Dicoelitid distribution pattern}

Reliable records of the earliest Dicoelitidae were reported from the Toarcian of western Canada in North America, where Conodicoelites has been well documented (Jeletzky 1980). This dicoelitid represents a component of the earliest belemnite fauna known from the north-eastern Pacific (e.g. Jeletzky 1980, Dzyuba et al. 2019). Other Toarcian records of dicoelitids elsewhere are less certain (Fig. 5). The presence of Conodicoelites in the Toarcian of southeastern Europe (Bosnia and Herzegovina) requires confirmation by new reliable data ( $c f$. Weis et al. 2015a). Supposedly true records of Dicoelites are known from the middle Toarcian-Aalenian of western and northern Canada in North America (Jeletzky 1980) and from the Toarcian (?) of China (southern Tibet) in eastern Asia (Wu 1982; for discussion see Iba et al. 2015). Therefore, the earliest 
distribution pattern of the dicoelitid genera Dicoelites and Conodicoelites is considered uncertain so far (e.g. Iba et al. 2015, Challinor \& Hudson 2017, Weis et al. 2017). It is not clear what area or even hemisphere was the centre of origin of the Dicoelitidae, the Northern Hemisphere [northeastern Pacific (?), western Tethys (?)] or the Southern Hemisphere (e.g. southern Tethys where southern Tibet was located in Jurassic times).

Whatever it was, prior to the appearance of dicoelitid belemnites in the Caucasian margin of the Tethys, they apparently had already existed in the west Tethyan seas and beyond (Fig. 5). Dicoelites is also known from the Bajocian of Argentina (Neuquén Basin) but was never illustrated (Doyle et al. 1997), whereas Dicoelites sp. A from the Upper Bajocian of Indonesia (Sula Islands) has been figured (Challinor et al. 1992). However, most of the reliable records of Dicoelites and Conodicoelites in the Southern Hemisphere come from the BathonianKimmeridgian from Somaliland, Madagascar, the Himalayas, Indonesia, Papua New Guinea, New Caledonia, New Zealand, and West Antarctica (for a summary see Stevens 1965a, Combémorel 1988, Challinor 1991, Doyle et al. 1997, Challinor \& Hikuroa 2007, Challinor \& Hudson 2017). According to Challinor (1991), some specimens of Belemnopsis described from the Middle Jurassic of Western Australia by Whitehouse (1924) could belong to Dicoelites, but Stevens (1965a) regarded them as Belemnopsis variants with a slightly developed dorsal groove. A few poorly preserved Dicoelites rostra were mentioned from the Upper Jurassic of Argentina and Chile (Stevens 1965b).

Taking into account that dicoelitids became relatively widespread and abundant in post-Bajocian times before their disappearance by the end of the Jurassic, we can conclude that our records from the Northern Caucasus contributes new data to the study of the early history of the distribution of this family.

\section{Conclusions}

Our study of dicoelitid belemnite specimens collected from the Upper Bajocian-Lower Bathonian of KarachayCherkessia (Northern Caucasus, southwest Russia) has revealed Dicoelites aprilis Dzyuba sp. nov., Dicoelites octobris Dzyuba sp. nov., Conodicoelites sp., and Conodicoelites exiguus (Krimholz, 1953). Both new species of Dicoelites have been established within the Upper Bajocian, indicating the range for the genus in the Northern Caucasus from the Baculatum Chronosubzone of the Niortense Chronozone up to the Parkinsoni Chronozone. They represent the first records of Dicoelites (s. str.) from the Upper Bajocian of Eastern Europe. Conodicoelites sp. is documented for the Upper Bajocian (Garantiana Chro- nozone), while the species $C$. exiguus is recorded from the Lower Bathonian (Zigzag Chronozone).

Dicoelites aprilis sp. nov. resembles members of the genus Belemnopsis (Belemnopseidae), while Dicoelites octobris sp. nov. resembles members of the genus Hibolithes (Belemnopseidae), but these new species possess a ventral alveolar groove in stable combination with a dorsal alveolar groove, which is a characteristic feature of the Dicoelitidae. New belemnite records from Karachay-Cherkessia contribute to a dicoelitid distribution pattern in the Middle Jurassic. Here, we provide evidence that the first appearance of Dicoelites in the European marginal seas of the Tethys Ocean and Conodicoelites in the Caucasian area of these seas occurred before mid-Late Bajocian time.

\section{Acknowledgements}

We are grateful to Vladimir V. Arkadiev (St. Petersburg) for photographs and information about the type series of Conodicoelites exiguus (Krimholz, 1953) and to Cynthia D. Schraer (Anchorage) for reading and English language editing of the manuscript. We thank the reviewers, Martin Košták (Prague) and Robert Weis (Luxembourg) for their helpful comments and valuable suggestions. This is a contribution to the RFBR (Russian Foundation for Basic Research) project no. 19-05-00130.

\section{References}

Adamia, Sh., Alania, V., Habukiani, A., Kutelia, Z. \& SadraDZE, N. 2011. Great Caucasus (Cavcasioni): a long-lived North-Tethyan Back-Arc Basin. Turkish Journal of Earth Sciences 20, 611-628.

BATHER, F.A. 1888. Shell growth in Cephalopoda (Siphonopoda). Annals and Magazine of Natural History 6(1), 298-310. DOI 10.1080/00222938809460727

Bayle, E. 1878. Fossiles principaux des terrains de la France. Atlas, 1-176. In Bayle, E. \& Zeiller, R. (eds) Explication de la carte géologique de France 4. Atlas. Part 1. Imprimerie Nationale, Paris.

Besnosov, N.V. 1967. Bajocian and Bathonian deposits of the Northern Caucasus. 179 pp. Nauka, Moscow. [in Russian]

Boenм, G. 1906. Geologische Mitteilungen aus dem IndoAustralischen Archipel. 1: Neues aus dem Indo-Australischen Archipel. Neues Jahrbuch für Mineralogie etc 22, 385-412.

Boeнм, G. 1912. Beiträge zur Geologie von NiederländischIndien. 1. Die Südküsten der Sula-Inseln Taliabu und Mangoli. 4. Unteres Callovien. Palaeontographica 3, 121-179.

Bülow-Trummer, E. von 1920. Fossilium catalogus 1. Animalia. Pars 11. Cephalopoda Dibranchiata. 313 pp. Junk, Berlin.

Callomon, J.H. 1964. Notes on the Callovian and Oxfordian 
Stages, 269-291. In Maubege, P.L. (ed.) Colloque du Jurassique à Luxembourg, 1962: comptes rendus et mémoires. Institut grand-ducal, Section des sciences naturelles, physiques et mathématiques, Luxembourg.

Callomon, J.H. 1985. The evolution of the Jurassic ammonite family Cardioceratidae. Special Papers in Palaeontology 33, 49-90.

Challinor, A.B. 1991. Belemnite successions and faunal provinces in the southwest Pacific, and the belemnites of Gondwana. BMR Journal of Australian Geology \& Geophysics 12, 301-325.

Challinor, A.B. \& Grant-Mackie, J.A. 1989. Jurassic Coleoidea of New Caledonia. Alcheringa 13(4), 269-304. DOI 10.1080/03115518908619051

Challinor, A.B. \& Hikuroa, D.C.H. 2007. New Middle and Upper Jurassic belemnite assemblages from West Antarctica (Latady Group, Ellsworth Land): taxonomy and paleobiogeography. Palaeontologia Electronica 10(1), 1-29. http: I/palaeo-electronica.org

Challinor, A.B. \& Hudson, N. 2017. Early and Middle Jurassic belemnites of New Zealand. Australasian Palaeontological Memoirs 50, 1-69.

Challinor, A.B., Doyle, P., Howlett, P.J. \& Nalnjaeva, T.I. 1992. Belemnites of the circum-Pacific region, 334-341, 636-645. In Westermann, G.E.G. (ed.) The Jurassic of the Circum-Pacific. Cambridge University press, Cambridge. DOI 10.1017/CBO9780511529375.025

Combémorel, R. 1988. Les bélemnites de Madagascar. Documents de la Laboratoire de Géologie de la Faculté des Sciences de Lyon 104, 1-239.

Doyle, P. \& Bennett, M.R. 1995. Belemnites in biostratigraphy. Palaeontology 38(4), 815-829.

Doyle, P. \& Kelly, S.R.A. 1988. The Jurassic and Cretaceous belemnites of Kong Karls Land, Svalbard. 77 pp. Norsk Polarinstitutt, Oslo.

Doyle, P., Kelly, S.R.A., Pirrie, D. \& Riccardi, A.C. 1997. Jurassic belemnite distribution patterns: implications of new data from Antarctica and Argentina. Alcheringa: An Australasian Journal of Palaeontology 21, 219-228. DOI 10.1080/03115519708619175

Dzyuba, O.S. \& Lagausie, B. de 2018. New belemnites (Megateuthididae, Cylindroteuthididae) from the Bajocian and Bathonian of the Yuryung-Tumus Peninsula, northern Siberia, Russia and their palaeobiogeographic implications. Paläontologische Zeitschrift 92, 87-105.

DOI 10.1007/s12542-017-0380-6

Dzyuba, O.S., Weis, R., Nalnjaeva, T.I. \& Riegraf, W. 2015. Rarobelus nom. nov. from the Boreal Toarcian-Aalenian and its systematic position (Belemnitida, Belemnitina, Megateuthididae). Neues Jahrbuch für Geologie und Paläontologie, Abhandlungen 275, 305-315.

DOI 10.1127/njgpa/2015/0465

Dzyuba, O.S., Goryacheva, A.A., Ruban, D.A., Gnezdilova, V.V. \& ZAYATS, P.P. 2016. New data on Callovian (Middle Jurassic) belemnites and palynomorphs from the Northern Caucasus, southwest Russia. Geologos 22(1), 49-59.

DOI 10.1515/logos-2016-0004
Dzyuba, O.S., Schraer, C.D., Hults, C.P., Blodgett, R.B. \& Schraer, D.J. 2019. Early Bajocian belemnites of Southcentral Alaska: new data and new perspectives on mid-Middle Jurassic Megateuthididae and Belemnopseidae biogeography. Journal of Systematic Palaeontology 17(11), 911-935. DOI 10.1080/14772019.2018.1486335

Gaković, M. \& Stoyanova-Vergilova, M. 1978. Conodicoelites riljensis spec. nov. (Belemnitida) from the Domerian in the Dinarides. Geoloshki Anali Balkanskoga Poluostrva 42, 413-420. [in Bulgarian with English summary]

GolonkA, J. 2011. Phanerozoic palaeoenvironment and palaeolithofacies maps of the Arctic region. Geological Society of London, Memoirs 35, 79-129. DOI 10.1144/M35.6

Iba, Y., Sano, S., Rao, X., Fuchs, D., Chenc, T., Weis, R. \& SHA, J. 2015. Early Jurassic belemnites from the Gondwana margin of the Southern Hemisphere - Sinemurian record from South Tibet. Gondwana Research 28, 882-887.

DOI 10.1016/j.gr.2014.06.007

Ippolitov, A.P. 2018a. Lower Bathonian belemnites and biostratigraphy of the central and southern parts of the East European Platform: Part 1. Megateuthididae. Stratigraphy and Geological Correlation 26(2), 179-205.

DOI 10.1134/S0869593818020041

IppoLitov, A.P. 2018b. Lower Bathonian belemnites and biostratigraphy of the central and southern parts of the East European Platform: Part 2. Cylindroteuthididae and Belemnotheutididae. Stratigraphy and Geological Correlation 26(4), 433-458. DOI 10.1134/S0869593818040020

Ippolitov, A.P. 2018c. Marine Early Bajocian deposits of the Lower Volga Region (Volgograd region) and their belemnitebased stratigraphy. Stratigraphy and Geological Correlation 26(3), 298-332. DOI 10.1134/S0869593818030073

Ippolitov, A.P. \& Desai, B.G. 2019. Dwarf megateuthidid belemnites from the Bathonian of Kachchh (India: Gujarat) and their significance for palaeobiogeography. Journal of Systematic Palaeontology 17(8), 613-634. DOI 10.1080/14772019.2018.1448471

Jeletzky, J.A. 1965. Taxonomy and phylogeny of fossil Coleoidea (= Dibranchiata). Geological Survey of Canada, Paper 65(2), 72-76. DOI 10.4095/121441

Jeletzky, J.A. 1980. Dicoelitid belemnites from the ToarcianMiddle Bajocian of western and Arctic Canada. Geological Survey of Canada, Bulletin 338, i-vii, 1-71. DOI 10.4095/109531

Krimholz, G.YA. 1931. Jurassic belemnites of the Crimea and Caucasus. Transactions of the Geological and Prospecting Service of U.S.S.R. 76, 1-52.

Krimholz, G.YA. 1953. Materials to the stratigraphy and fauna of the Lower and Middle Jurassic of the Caucasus. Uchenye Zapiski Leningradskogo Gosudarstvennogo Universiteta 159, 25-58. [in Russian]

Krimholz, G.YA. \& Repin, Yu.S. 1989. About few Jurassic guards from Iran and belemnitid's commissure, 86-93. In Soloviev, V.A. (ed.) Stage and zonal scales of the Boreal Mesozoic of the USSR. Nauka, Moscow. [in Russian]

Loriol, P. DE \& Pellat, E. 1874. Monographie paléontologique des étages supérieurs de la formation Jurassique des environs 
de Boulogne-sur-Mer. Mémoires de la Société de Physique et d'Histoire Naturelle de Genève 24, 1-292.

MAYER, K. 1866. Diagnoses de bélemnites nouvelles. Journal of Conchology 3(6), 358-369.

MitTA, V.V. 2015. Genus Oraniceras (Parkinsoniidae, Ammonoidea) from the Lower Bathonian of southern European Russia. Paleontological Journal 49(6), 595-601. DOI 10.1134/S0031030115060088

MitTA, V.V. 2017a. On some Rarecostites (Parkinsoniidae, Ammonoidea) from the Upper Bajocian Parkinsoni zone of the Northern Caucasus. Paleontological Journal 51(5), 464-479. DOI 10.1134/S0031030117050057

MitTA, V.V. 2017b. The ammonoid genus Spiroceras (Spiroceratidae, Ammonoidea) from the Upper Bajocian of the Northern Caucasus. Paleontological Journal 51(2), 133-142. DOI 10.1134/S0031030117020101

MıтtA, V.V. 2017c. The genus Keppleritiana gen. nov. (Stephanoceratidae, Ammonoidea) from the Upper Bajocian of the Northern Caucasus. Paleontological Journal 51(3), 247-257. DOI 10.1134/S0031030117030066

MitTA, V.V. 2018. On the first finds of the genus Djanaliparkinsonia (Stephanoceratidae, Ammonoidea) in the Upper Bajocian of the Northern Caucasus. Paleontological Journal 52(4), 379-388. DOI 10.1134/S0031030118040093

MitTA, V.V. 2019. Ammonites and stratigraphy of the Upper Bajocian Garantiana garantiana Zone in the interfluve between the Kuban and Urup rivers (Northern Caucasus). Paleontological Journal 53(11), 72-86.

DOI 10.1134/S0031030119110066

Mitta, V.V. \& Schweigert, G. 2016. A new morphotype of lower jaw associated with Calliphylloceras (Cephalopoda: Ammonoidea) from the Middle Jurassic of the Northern Caucasus. Paläontologische Zeitschrift 90(2), 293-297. DOI 10.1007/s12542-016-0288-6

Mitta, V.V. \& Sherstyukov, M.P. 2014. On the Bajocian and Bathonian of Bolshoy Zelenchuk River Basin (Northern Caucasus), 74-81. In Ivanov, A.V. (ed.) Problems of paleoecology and historical geoecology. Saratov State Technical University, Saratov. [in Russian]

MitTA, V.V. \& Sherstyukov, M.P. 2018. First record of Patrulia (Ammonoidea: Stephanoceratidae) in the Upper Bajocian of the Northern Caucasus, Russia. Neues Jahrbuch für Geologie und Paläontologie, Abhandlungen 288(3), 251-254. DOI 10.1127/njgpa/2018/0739

Mitta, V.V., Savelieva, Ju.N., Fedorova, A.A. \& Shurekova, O.V. 2017. Biostratigraphy of the Bajocian-Bathonian boundary beds in the basin of the Bolshoi Zelenchuk River (Northern Caucasus). Stratigraphy and Geological Correlation 25(6), 607-626. DOI 10.1134/S0869593817060065

Mitta, V.V., Savelieva, Ju.N., Fedorova, A.A. \& Shurekova, O.V. 2018. Ammonites, microfauna and palynomorphs from the lower part of the Upper Bajocian Parkinsoni Zone of the basin of the Bolshoi Zelenchuk River, Northern Caucasus. Stratigraphy and Geological Correlation 26(5), 552-570. DOI 10.1134/S0869593818050040

Montfort, P.D. DE. 1808. Conchyliologie systématique, et classification méthodique des coquilles; offrant leurs figures, leur arrangement générique, leurs descriptions caractéristiques, leurs noms; ainsi que leur synonymie en plusieurs langues. Tome 1. 409 pp. F. Schoell, Paris.

NaEf, A. 1922. Die fossilen Tintenfische. Eine paläozoologische Monographie. 322 pp. Gustav Fischer, Jena.

DOI 10.5962/bhl.title.2082

Neumayr, M. 1871. Die Cephalopoden-Fauna der Oolith von Balin bei Krakau. Abhandlungen der Kaiserlich-königlichen Geologischen Reichanstalt 5(2), 19-54.

Nikishin, A.M., Ziegler, P.A., Bolotov, S.N. \& Fokin, P.A. 2012. Late Palaeozoic to Cenozoic evolution of the Black Sea-southern Eastern Europe region: a view from the Russian Platform. Turkish Journal of Earth Sciences 21(5), 571-634.

Ooster, W.A. 1857. Catalogue des Céphalopodes fossiles des alpes suisses: avec la description et les figures des espèces remarquables 1: Céphalopodes acétabulifères. 32 pp. Imprimerie de Zurcher et Furrer, Zurich.

Polyansky, B.V. 1989. Mesozoic coal-bearing formations of the Mesotethys northern margin. 192 pp. Nauka, Moscow. [in Russian]

Pugaczewska, H. 1961. Belemnoids from the Jurassic of Poland. Acta Paleontologica Polonica 6, 105-236.

Rostovtsev, K.O., Agaev, V.B., Azarian, N.R., Babaev, R.G., Besnosov, N.V., Hassanov, N.A. et al. 1992. Jurassic of the Caucasus. 192 pp. Nauka, St. Petersburg. [in Russian]

Rothpletz, A. 1892. Die Perm-, Trias- und Jura-Formation auf Timor und Rotti im Indischen Archipel. Palaeontographica 39(2-3), 57-106.

Ruban, D.A. 2006. The palaeogeographic outlines of the Caucasus in the Jurassic: the Caucasian Sea and the Neotethys Ocean. Geološki Anali Balkanskoga Poluostrva 67, 1-11. DOI 10.2298/GABP0667001R

Sachs, V.N. \& Nalnjaeva, T.I. 1967. Recognition of the superfamily Passaloteuthaceae in the suborder Belemnoidea (Cephalopoda, Dibranchia, Decapoda). Doklady Akademii Nauk SSSR 173(2), 438-441. [in Russian]

SAchs, V.N. \& NALnjaeVA, T.I. 1975. Early and Middle Jurassic belemnites of the northern USSR. Megateuthinae and Pseudodicoelitinae. 192 pp. Nauka, Moscow. [in Russian]

Scotese, C.R. 2004. A Continental Drift Flipbook. The Journal of Geology 112, 729-741. DOI 10.1086/424867

Sibiryakova, L.V. 1961. The problem of oil-and-gas-bearing capacity of Central Asia 5: Middle Jurassic molluscan fauna of the Great Balkhan and its stratigraphic value. 233 pp. Gostoptekhizdat, Leningrad. [in Russian]

Stevens, G.R. 1965a. The belemnite genera Dicoelites Boehm and Prodicoelites Stolley. Palaeontology 7(4), 606-620.

Stevens, G.R. 1965b. The Jurassic and Cretaceous belemnites of New Zealand and a review of the Jurassic and Cretaceous belemnites of the Indo-Pacific Region. New Zealand Geological Survey, Paleontological Bulletin 36, 1-283.

Stoyanova-Vergilova, M. 1979. Bathonian belemnites from Bulgaria. Geologica Balcanica 9(4), 47-58.

Terquem, O. \& Jourdy, E. 1869. Monographie de l'étage Bathonien dans le département de la Moselle. Mémoires de la Société Géologique de France (2), 9(1), 1-175.

DOI 10.5962/bhl.title.11874 
Weis, R., Mariotti, N. \& Di Cencio, A. 2015a. Systematics and evolutionary implications of Early Jurassic belemnites from the Peri-Mediterranean Tethys. Paläontologische Zeitschrift 89(4), 729-747. DOI 10.1007/s12542-015-0265-5

Weis, R., Mariotti, N. \& Wendt, J. 2015b. The belemnite genus Rhabdobelus from Middle Jurassic Tethyan sediments of central Italy and Sicily, with a systematic review. Paläontologische Zeitschrift 89(2), 133-146.

DOI 10.1007/s12542-014-0223-7

Weis, R., SAdki, D. \& Mariotti, N. 2017. Aalenian-Bajocian belemnites from the Middle and High Atlas, Morocco: taxonomy, biostratigraphy and palaeobiogeographical affinities. Neues Jahrbuch für Geologie und Paläontologie, Abhandlungen 284(2), 215-240.

DOI 10.1127/njgpa/2017/0659

Westermann, G.E.G. 2000. Marine faunal realms of the Meso- zoic: review and revision under the new guidelines for biogeographic classification and nomenclature. Palaeogeography, Palaeoclimatology, Palaeoecology 163, 49-68. DOI 10.1016/S0031-0182(00)00142-5

Whitehouse, F.W. 1924. Some Jurassic fossils from Western Australia. Journal of the Royal Society of Western Australia 11, 1-13. DOI 10.5694/j.1326-5377.1924.tb65604.x

Wu, S. 1982. Characteristics of Early Jurassic-Early Cretaceous belemnoid assemblages from southern Xizang (Tibet). Contribution to the Geology of the Qinghai-Xizang (Tibet) Plateau 10, 113-121. [in Chinese]

Zhamoida, A.I. (ed.) 2006. Stratigraphic Code of Russia. Third edition. 96 pp. VSEGEI Press, St. Petersburg. [in Russian]

Zittel, K.A. von 1895. Grundzüge der Palaeontologie (Palaeozoologie). 971 pp. Oldenbourg, München-Leipzig. 